\title{
User-Involved Universal Design Experience in The Space, Product and Service
} Development Process

\section{Lütfi Hidayetoğlu* M. Kübra Müezzinoğlu*}

Abstract

Designs aimed at the involvement of disabled people in social life are thought to bring the disabled users into a situation isolating them from the society. This study aims to emphasize that with the use of universal design principles, rather than making different designs for each user group, the space, products and services available to everyone can be revealed. This study was carried out with the view that space, products and services designed by universal design principles can be used by the disabled and that the disabled are an integral part of the society. The study was conducted with three study groups, which were formed by the active involvement of disabled individuals. Working groups focused on designs that can serve all users with reference to the experiences, expectations and needs of individuals with disabilities. At the end of the study, groups designed spaces, products and services that meet the needs of disabled people with universal design principles and provide routine participation in social life.
Keywords: Universal design, disability concept, disability types, universal design principles, user-focused design

*Assoc. Prof. Dr., Faculty of Fine Arts, Department of Industrial Design, Selcuk University, Konya, Turkey.

E-mail: mlhidayetoglu@selcuk.edu.tr Orcid ID: http://orcid.org/0000-0002-97201700

**Dr. Inst., Faculty of Fine Arts, Department of Interior Architecture and Enviromental Design, Selcuk University, Konya, Turkey.

E-mail: kubramzzn@selcuk.edu.tr Orcid ID: http://orcid.org/0000-0001-58086618 


\section{INTRODUCTION}

Disabled individuals at the forefront of disadvantaged groups and designs for them are aimed to involve the disabled in social life. However, these designs, made specifically for the disabled, are dragging them into a process that separates and isolates the disabled people from the rest of society. It is considered to be possible that the expectations of all user groups can be met and individuals with disabilities can be included in social life without any problems with the designs created by considering the user needs with universal approach. The studies done by The World Health Organization (WHO) have indicated that about one quarter of the world's individuals are directly or indirectly confronted with some form of disability in their lives.

According to figures published by the UN, it is known that there are around 500 million people with disabilities in the world (URL1). According to the researches done by Turkey Statistical Institute (TSI) in 2010, there are 280.014 people reported in the medical report to have at least $20 \%$ disability rate, recorded in the National Disability Database and living in the borders of the Republic of Turkey and (URL-2). This data shows how important the disabled population has a place in the general population and brings some facts to light. According to this data, the reason why we are not able to meet a large number of people with disabilities in streets in our daily lives is that they are exposed to some physical and psychological obstacles in daily life rather than a small number of individuals with disabilities. However, disabled people also have the right to benefit freely from all possibilities that society benefits as much as everyone else. Equal access to this right is possible only when the necessary legal and spatial arrangements are made and the needs of disabled individuals are taken into account.

It is quite significant to be able to perceive individuals who are defined as disabled as an integral part of society rather than as a separate part, and to provide this with space, product and service designs. In this respect, the concept of universal design and the accessibility of this concept become a current issue. Universal Design is defined as the design of spaces, products and services that are equally accessible and usable by different groups of people of different ages, sizes, genders, interests and skills. It is one of the main objectives of this study to make awareness of this design concept especially by the designers, draw attention to different user groups forming the society and to produce solutions for the individuals whose lives are restricted due to deficiencies and errors caused by the design. 


\section{DEFINITIONS and BASIC CONCEPTS}

Historical development process of the literature concepts, the principles that make up the concepts and the current approaches added to these principles have been studied through examples and universal design principles have been examined through examples in terms of space, product and service designs in this chapter, where definitions and concepts belonging to universal design are examined.

\section{Disability Concept and Types}

People with disabilities due to innate or later loss of their physical, psychological, sensual and social skills at various levels due to natural disasters, malnutrition, illness or accidents are obstructing their vital activities partially or completely and most importantly making it difficult for them to continue their social life (Aytaç, 2005, Beşer et al., 2006).

In the literature studies, it has been determined that various organizations have different definitions about disabled individuals. Uskun et al., (2005) notes that the expected benefits can not be obtained from the studies due to not using the appropriate classifications in the researches, the confusion about the concepts of disability, handicap or impairment, not being able to draw their boundaries precisely, and having no fixed standard between countries.

As a result of the researches made on this issue; the definitions of disability made by The United Nations (UN), the International Labour Organization (ILO) and the Turkey Statistics Institute (TUIK) are given below;

According to the Article 1 of the Declaration of the Rights of Disabilities, annex numbered 3447 of the Universal Declaration of Human Rights that was enacted on 9 December 1975 in the UN General Assembly, disabled individuals are defined as "people who are unable to do the things to be done in a normal person's personal or social life due to any innate or later deficiency in their physical or mental abilities" (United Nations, 1975).

The International Labour Organization (ILO) defines disability as "a person with a further decline in the achievement or maintenance of a suitable work, resulting in a reduction in physical and mental abilities" (International Labour Organization, 2008).

According to the definition of disability made by Turkey Statistical Institute (TSI), disabled people are those "who are unable to comply with the requirements of normal life owing to the loss of 
physical, mental, spiritual, sensory and social skills at various levels by birth or later for any reason and is in need of special physical arrangements in structures and open spaces" (DIE, 2004).

As it is understood from these definitions, the disability may be caused by innate or later illness or accident; loss of function in physical or mental activities that the individual must perform in his or her daily life, resulting from limitation or inability to perform within the limitations normal or considered normal; it can also be defined as the difficulties that can be experienced in activities such as seeing, hearing, speaking, learning, grasping, accessing, washing, eating, going to the toilet, involving in work and social life.

In order for the needs and wishes of disabled people to be determined and met, it is first necessary to know the types of disabled people and then to make appropriate designs according to the types of disabilities. DIE (2004) classifies disability as orthopedically disabled, sight disabled, hearing disabled, language and speech disabled, mentally disabled and other disabled (DIE, 2004). Orthopedic disabled are those with inadequacy, deficiency and loss of function in the musculoskeletal system. Sight disabled are those with complete or partial visual loss or impairment in one or both eyes. Hearing disabled are those who have complete or partial hearing loss in one or both ears. Language and speech disabled are those who are unable to speak for any reason or have impairment at the speed of speech, fluency and voice impairment. Mentally disabled are people with various degrees of mental disability. People having illnesses that require continuous care and treatment, which cause work capacity and functions to be hindered, also fall into the other group of disabilities. This group also includes people with blood diseases, cardiovascular diseases, respiratory system diseases, digestive system diseases, urinary tract and reproductive tract diseases, cancers, endocrine and metabolic diseases, mental disorders, nervous system diseases and HIV (DIE, 2004).

User groups do not have only disabled individuals. Individuals need different design arrangements and standards during their lifetimes (eg, infancy, childhood, old age, etc.) or situations (illness, disability, pregnancy etc.) (Tutal, 2013). The main idea in this conception is to design environment and products that can be used by the maximum number of potential people, without the need for special design and adaptation based on the fact that all people have disabilities for some reason, such as age, skill loss, etc. (Dostoğlu et al., 2009). 


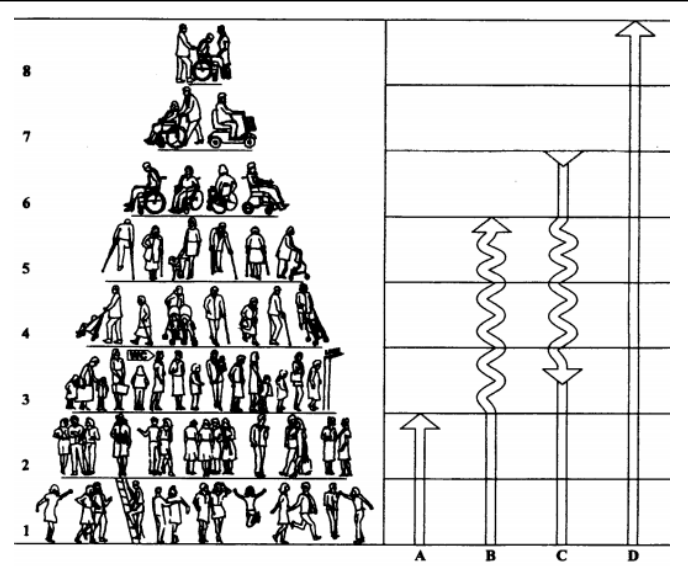

The best explanation of reaching the maximum number of potential users is seen in Goldsmith's "Universal Design Pyramid" (Figure 1). The users in the first two steps of the pyramid express the healthy and energetic people who can be burdened with heavy burdens and jobs, while the third line refers to the individuals with normal competence. The users in the fourth step of the pyramid are the disabled group according to the environment designed, arrangement or the suitability of the design, while the fifth and sixth step of the pyramid refers to the user group on which the universal design is based. The reason for this is that the designs made for the user group in this step are more inclusive as they include people in their subgroups. With a similar approach, Hazer (2005) emphasizes that design approaches based on the needs and desires of the individuals in the disadvantaged group will provide comfortable use for people in the other population group.

\section{Universal Design Concept}

When examining the historical evolution process of industrial product design, it is seen that many parameters are examined from technological developments, economic and political systems to the change of value judgments in society. From the production of handicrafts in which fewer products are manufactured, to the serial production with the industrial revolution, the problems that have emerged throughout the world and their solutions have been searched (Evcil, 2014).

The universal design approach, the main idea of which is to avoid separating or dismissing any user, is described by North Carolina State University's Universal Design Center as "products and environments to be used by people of all ages and abilities to the highest possible extent" (Story, 2001).

Olguntürk (2007) states that universal design is a holistic philosophy that opposes the treatment of individuals with disabilities as a special group, while Evcil (2014) notes that the
Figure 1. The Universal Design Pyramid (Goldsmith, 2000) 
adoption of this philosophy by both users, designers and administrators is considered as a level of maturity reached by societies today. This concept is called "inclusive design" in America; however, it is called "design for all" in Europe (Ostroff, 2001). This term is replaced by various expressions such as life span design, trans generational design, user needs design, and real life design; while Dostoğlu et al. (2009), relating this diversity in terminology to the social and cultural differences of societies also points out that all differences affect the way in which the universal design approach is adopted and the way it is developed. All these concepts are based on common goals such as comfort, security, embracing everybody, sufficiency, independence, involvement, sustainability, integration, cultural compatibility, gender appropriateness, inclusion and material accessibility.

The universal design approach, expressed as the design paradigm of the 21st century (Preiser, 2008), has been the work of many researchers and each has defined this concept in different ways. According to Goldsmith (2000) and Ostroff (2001), universal design is a holistic, integrated, and transparent approach that includes accessibility requirements, detailing the elements of the system at the beginning, and then connecting subsystems until the top system is complete. While Hanson (2004) states that the universal design approach is the ideal system of thinking that is achieved by being separated from other design methods by being participatory, democratic, heterogeneous, low cost and user oriented; Evcil (2014) defines universal design as a search for the ideal rather than a finished state by producing innovative and pioneering alternative solutions according to changing and developing human needs. According to Knetch (2004, quoted in Evcil, 2014), drawing attention to the fact that the universal design approach is a movement around the world, this design concept aims to form a framework for generating solutions rather than specifying a specific goal.

The universal design concept first began to be used by American architect Ronald L. Mace, who lived in the mid-1980s, dependent on a wheelchair after suffering from polio in childhood (Kavak, 2010). In his speech at the "Designing for the 21st Century: An International Conference on Universal Design" conference held in New York in 1998, Mace expressed that the concept of unobstructed design is completely different from the universal design; that unobstructed design aims to provide solutions to individual needs alone while the universal design aims to facilitate the life of all users; and assistive technologies can offer only individual solutions, just like their own wheelchair (Jacobs, 1961). 
The concept of universal design, expressed by Hanson (2004) as a macro-environmental approach, aims to reach situations where a single user is not even excluded, by broadening design parameters and reject all positive or negative discrimination. This design approach, which offers intelligent design solutions to make life easier for all users, and which then needs to be easy to understand, modern and highly aesthetic in form language (Zec, 2009), also improves individual performance, health and social involvement (Steinfeld and Massel, 2012).

\section{The Universal Design Principles}

The concept of universal design is presented in its own history with good examples representing some aspects of it rather than describing the characteristics of a particular period concept, since there is no formalized criterion that could define the question of how to make a design most usable (Evcil, 2014). But then, in search of whether we can bring the concept of "maximum availability" for universal design into measurability in order to be able to design a period of available products and accessible environments, we have been searching for some accessibility codes such as ADA (the American with Disabilities Act Standard for Accessible Design Institute), and usability criteria such as ANSI (American National Standards Institute) and ISO (International Standards Organization) Standards. However, these standards have been limited to specific products and environments, necessitating the designation of principles that guide the universal design process (Story, 2001). Because it has been understood that the universal design should be regarded as part of the decision-making process rather than as a final product (Evcil, 2014).

On April 28-29, 1995, a team of ten people consisting of architects, product designers, engineers and environmental design researchers came together at the Center for Universal Design at the State University of North Carolina, and created the "Universal Design Principles" in order to guide the professionals for the presentation of environment and product designs on the basis of concepts of "equal status, equal behaviour, equal value" (Boduroğlu, 2005). The first draft was created on May 22, 1995 and the second on July 26,1995; and the principles were finalized on April 1, 1997 as follows (Evcil, 2014):

Principle 1: Equality in use (fair use)

Principle 2: Flexibility in use

Principle 3: Simple and intuitive use

Principle 4: Comprehensible information 
Principle 5: Fault tolerance

Principle 6: Low physical effort

Principle 7: Size and area required for approach and use

Researchers who continue Ron Mace's mission are still working today to develop these principles, though (Evcil, 2014). Mr. Satoshi Nakagawa, the manager of a Japanese design company named "Tripod Design" added three new principles to the "Product Performance Program" inspired by universal design principles in 2006, in order to objectively evaluate the universal design performance of a design (Evcil, 2014). Evcil stated that three new principles were added to the 7 principles mentioned in the book "Design for All" published in 2014. These principles are as follows:

* Adding to Human Delight (Manley, 2000, Evcil, 2014)

* Product Durability and Production Economics (Nakagawa, 2006)

* People's Health and Natural Environment (Nakagawa, 2006)

*Functional and Aesthetic Integration (Değertekin, 2010, Nakagawa, 2006, Evcil, 2014)

* Social Cohesion and Participation (Değertekin, 2010, Evcil, 2014)

Universal design is not a trend, but a permanent design approach that assumes that the kinds of human abilities are ordinary, not special (Ostroff, 2001). The aim of universal design principles and related rules is to express the concept of universal design in a comprehensive way. The principles help educate all designers and consumers about the features of more useful design solutions. In addition, these principles, which constitute a specific standard, can also be used to guide the design process as it allows systematic evaluation of designs. They also allow for the development and implementation of the inclusion approach in the construction of the principles in many areas.

In addition, there is no obligation to implement all of these principles at once that increase and improve the demand for functional product design, which enables access to a large number of users. This approach, which basically includes the principle of equal use, can only be done gradually in the design process. Because universal design, aiming at providing the conditions that bring the least effort to human soul and body, is not a set of rules but an application philosophy and a common sense approach (Zimmerman, 2006, Akyol, 2009). 
Within the scope of this study, universal design principles are divided into subheadings in terms of space, product and service designs since they are aimed to recognize, listen, understand and even experience the physical environment, product and service together with individuals having different types of disabilities. In the next section, the existing examples of these classifications will be given.

\section{Universal Design Principles in terms of Space Design}

Since the individuals in society have equal rights to socialize and to live their cultural life freely, it is necessary to design spaces that can be shared by all healthy and disabled individuals and prevent social loneliness. Even though the differences in movement of people moving within the same space is mainly are due to the differentiation of personal characteristics, this does not necessarily require to be a disabled or not disabled user. Therefore, universal design encourages users to make spatial designs without distinction.

In addition to building vertical circulation elements such as building entrances, common areas, toilets, ramps, elevators and ladders, according to the standards appropriate to the disabled to create accessible design; indoor and outdoor solutions should be made where healthy individuals as well as disabled can coexist without isolation from social life, and horizontal and vertical access schemes should be established.

The space designs of the universal design principles covered in the research were examined by supporting the following examples.

Table 1. Examples of universal design principles in terms of space design

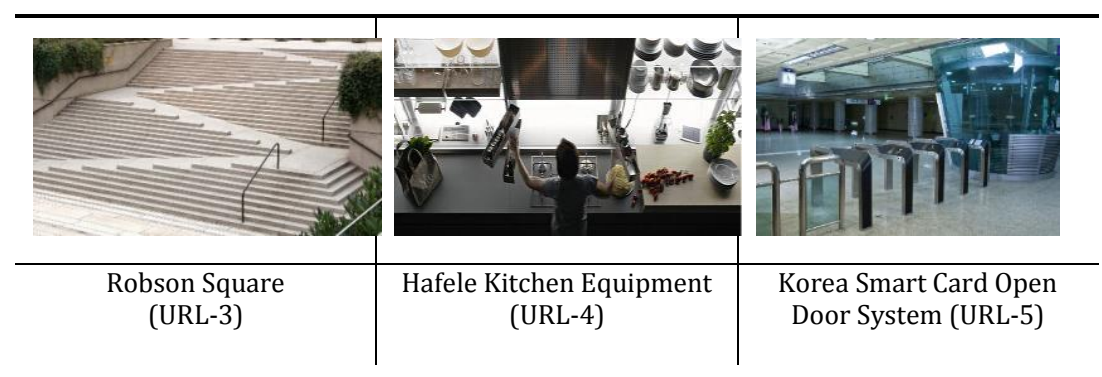

Designed by Arthur Erickson, "Robson Square" is one of the most important examples of how successful the universal design principles can lead to social integration and involvement principles. When the design of the square is examined, it is seen that there are various alternatives for the users in terms of circulation in the square, that the circulation on the sloping ground is provided not only by the ladder but also by the ramps and at the same time the ramps within the square are not separated from the square. 
Developed by "Hafele" company on easy transportation and access concepts; kitchen equipments have applications and solutions that meet all the principles of universal design that everyone can use, including children, the elderly and disabled users.

"Korea Smart Card Open Door System" was designed by Yongtae Kim in 2011. Its design is the best example recently designed based on the principles of equal use principle. The bi-directional design allows the human traffic to flow more regularly, while allowing the wheelchair users to switch freely thanks to the optimum width.

Table 2. Examples of universal design principles in terms of space design

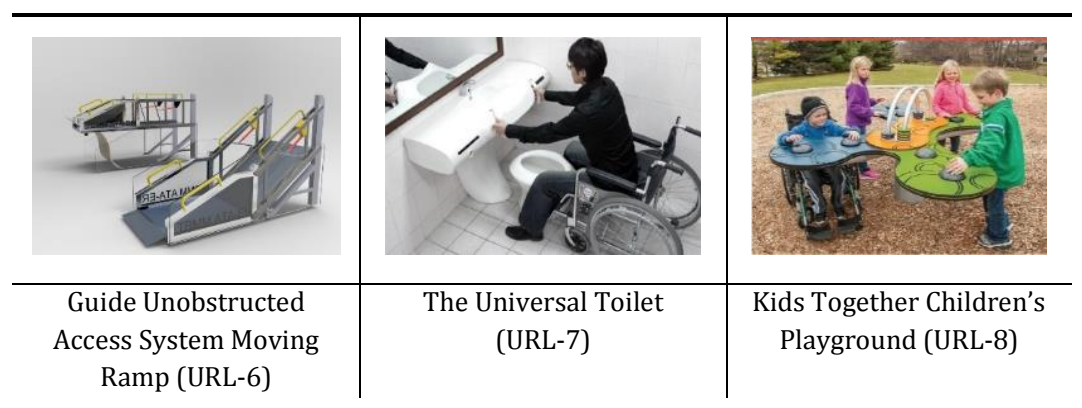

The "Guide Unobstructed Access System Moving Ramp", which was awarded the Good Design Award and Design Turkey 2017, was designed by Ataman Özdemir. Inspired by the ramps placed next to the stairs, this project will be applied in stairs with a height of $100-150 \mathrm{~cm}$ and has an elevator structure that gradually reduces its slope.

In "The Universal Toilet" designed by Changduk Kim \& Youngki Hong, it is not necessary for the users to turn around or turn the wheelchair. Simply sliding the wheelchair forward is sufficient for use.

Located in North Carolina, the park was built as a reflection of the universal design concept to offer playgrounds and artistic activities for children of all ages and physical abilities. By combining natural and artificial landscape elements, the park aims to meet the needs of children and their parents regardless of their ability and age.

\section{Universal Design Principles in Terms of Product Design}

Once the individual has used and experienced a product for the first time, he/she compares the performance of the product with the expectations in the mind before using the product. This comparison results in a difference between expectation and performance (perception). This difference indicates satisfaction 
User-Involved Universal Design Experience in The Space, Product and Service Development Process

in positive direction and dissatisfaction in negative direction (Bitner, 1990, Oliver, 1997).

A well designed product that is suitable for everyone's use and that produces positive results in terms of universal design principles should allow for equal use and offer flexibility, simplicity, comprehensibility, perceptibility, minimization of danger, comfort and accessibility in accordance with personal preference and abilities.

The product designs of the universal design principles covered in the scope of the research were examined by supporting the following examples.

Table 3. Examples of universal design principles in terms of product design

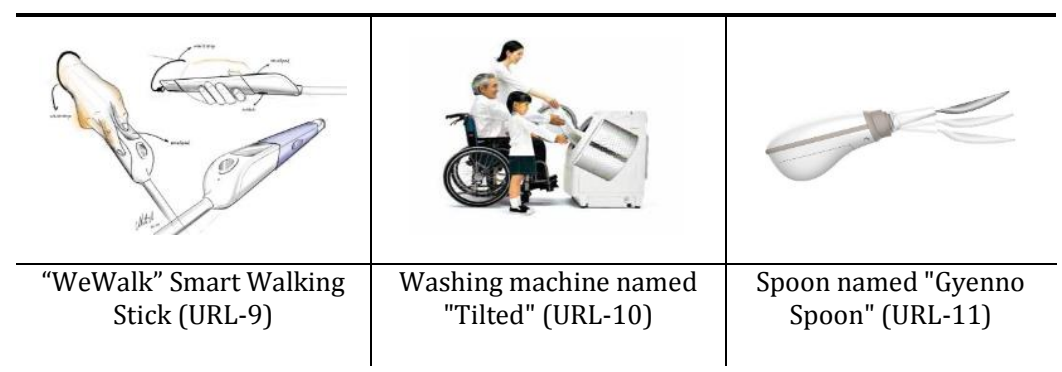

The world's first smart walking stick named "WeWalk" is designed to make life easier for sight disabled people. As the holding part of the walking stick goes from thick to thin, it is compatible with all kinds of hand structure and holding. It also offers multiple services to the user thanks to the obstruction detection mode and integration with the phone.

The washing machine named "Tilted" produced by Panasonic in 2003 , aiming at offering easy use for the elderly, is equipped with an angled lid design and a hoop which is placed at an angle of about 30 degrees compared to standard washing machines, allowing users to protect their natural body positions without bending effort.

"Gyenno Spoon" is a spoon with anti-tremor feature designed by Google for Parkinson patients. The spoon, which allows the patients to eat more comfortably, is able to perceive the hand tremor and remain in balance at the same time. 
Table 4. Examples of universal design principles in terms of product design

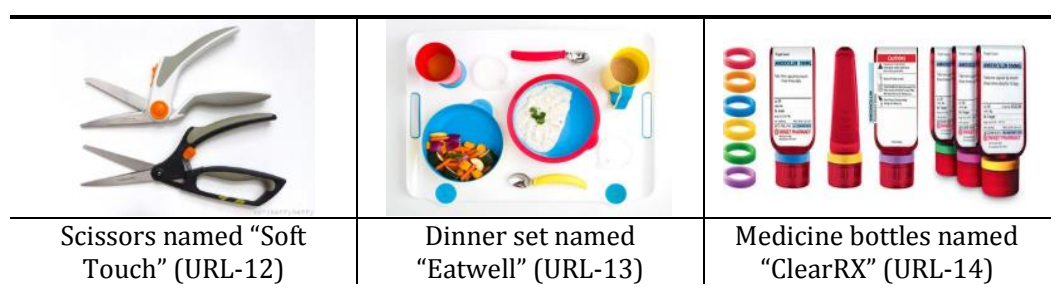

Fiskars company offers the finest examples of the principle of flexibility in use with the scissors with distinctive features. The product provides convenient options for both right hand and left hand users while offering optional usage options with a handy shape and natural movements.

The designer Sha Yao designed a dining set called "Eatwell" that would make life easier for people suffering from dementia. The bottoms of the plates and glasses are designed to be angled so that the dishes and beverages can be gathered on one side with natural inclination to make it easy to take with the spoon and drink. This facilitates the work of patients having difficulties in putting food on spoon due to hand tremor.

Designed for Target Company, "ClearRX" medicine bottles are specifically designed for users with a problem of forgetfulness and reduced vision. The label with large size and hierarchical information enables to distinguish the elements in identifiable shapes by improving the readability to the highest level with the color-coded rings that distinguish the drug type.

\section{Universal Design Principles in Terms of Service Provision}

According to the United Nations Environment Program (2009); service design is to meet product systems, services and the necessary infrastructure in a more effective way with the value to be reached both to the business lines and to the customers in line with the demands and needs of the customers. This approach is a model that provides an integrated mix of products and services between value-creation system stakeholders that provide environmentally-friendly economic and competitive new solutions and innovation-based interactions to meet a specific customer demand (Vezzoli, 2014).

The study of systems that offer an alternative to individual use of a product in order to substitute a service with an object is considered within the scope of service design.

The service applications of the universal design principles covered in the scope of the research have been examined by supporting with the example given below. 
Table 5. Examples of universal design principles in terms of service design

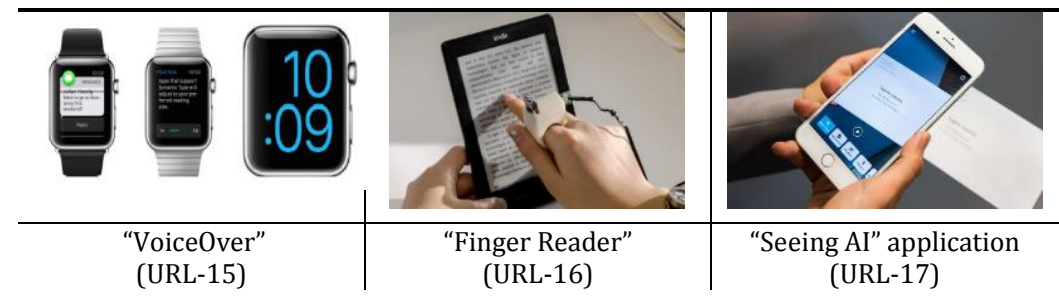

"VoiceOver" is the world's first motion-based screen reader developed for use on Mac and OS devices so people with sight disability or low vision can understand and control what's on their device. FaceTime allows users with hearing and speech difficulties to speak using all kinds of face expressions, while offering multitouch movements with one finger for users with physical disabilities and lack of motor skills.

"Finger Reader" allows the sight disabled to write text by using their hands as a keyboard. Thanks to the sensors mounted on the finger, the hand and finger movements of the sight disabled are transferred to the main computer, and they are translated to the letters coded according to the sign language with the help of a special software.

The "Seeing AI" application by Microsoft, which can work with smartphones or smart glasses, conveys everything that happens in front of the individual to the user. In addition, the application conveys the age, sex and feelings of the people around to the user.

In addition, ÖSYM (Student Selection and Placement Center) and Open Education Institutions providing education and training services in our country provide a special service provision for students with disabilities. Prior to the examinations, if the individuals with disability apply to the centres with a petition and medical report, the individual is taken to the examination room and accompanied by an assistant who will mark the answer sheet for the students who are unable to use their hands.

As can be seen from the examples that are examined, the needs of the users are generally preliminary in the designs of the spaces, the products they use and the services they are in. It is the "average user" needs that are often considered in the design phase, though. Designs in all kinds of spaces, products and service design groups from staircase design to parks, kitchenware to furniture, mobile devices to white goods and automotive sector should provide harmonious coexistence of user friendly and environmentally friendly approaches. 


\section{RESEARCH METHOD}

Because of the diversity of users in society, as well as important changes in society, technological developments and increasing levels of education; people have begun to live more independently, and the spaces, products and services they have used have become more universal. As this design area expands, the importance of universal design education has also increased. Many departments of design education placed universal designbased approaches in their curriculum, these approaches were studied in the studio lessons as project themes or universal design-focused workshops were organized.

This process, which is open to the development of universal design, led to the need for content and educational materials. For this purpose, an activity was organized by Selcuk University Department of Architecture on 3-4 May 2018 with the theme "Thinking with Universal Design" (Figure 1,2). The aim of this activity is to understand universal design, to be able to think with universal design principles in design and to offer solution proposals about city and space. At this point, the awareness of young designers is expected to increase. On the first day of the event, the panel speakers gave information to participants about the universal design examples and applications in Turkey and in the world. On the second day of the event, a workshop was conducted under the leadership of the panel speakers, and afterwards the resulting products were presented to all participants.

Figures 1, 2. Event announcement text and poster
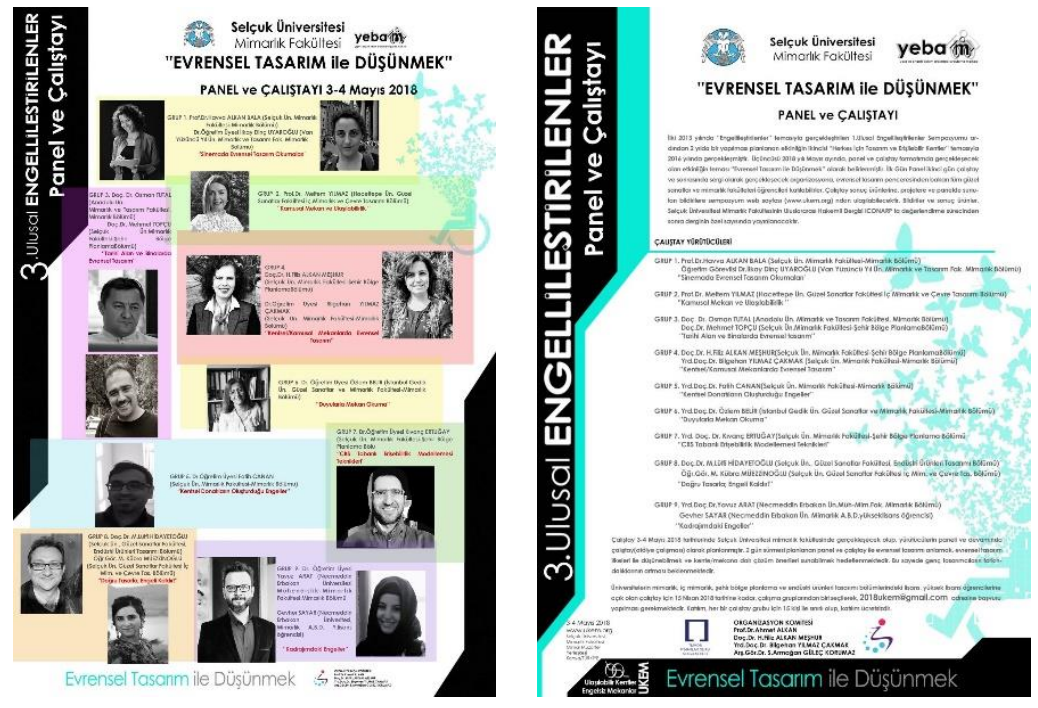

In a workshop themed "Group 8: Design Right; Remove the Obstacles", conducted by Assoc. Dr. M. Lütfi Hidayetoğlu, Dr. Inst. M. Kübra Müezzinoğlu and 15 students who have undergraduate studies in different departments in the field of design; it is aimed 
to get to know, listen, understand and even experience a product, service or physical environment together with individuals with different types of disabilities. First, some elements have been identified for students to make universal design more effective, useful and instructive. Opportunities for attitudinal change and critical thinking have been created for students in order to increase the influence of these elements and to increase their skills and knowledge about the process.

Even if differences and diversity in humans are seen and perceived, they may not be sufficiently sensitive to consider the problems they are experiencing. The workshop was carried out with the aim of educating and developing the sensitivity of individuals with disabilities, and for students to communicate with other people and to design by feeling responsibility for them. Within the scope of the workshop, 3 groups were allocated to design space, product and service so that the students would be in equal numbers and each group was accompanied by an individual with sight disability, orthopedic disability and hand-arm deficiency.

Before moving on to the design stage, all groups were provided with a period of time spent with a disabled individual who accompanied them in a social environment for a while. They were then interviewed to find out their personal needs and distress in the community and to develop solution proposals that would eliminate these problems altogether. After an hour of interviews with disabled people, the first meeting was held with workshop directors to find answers to questions about what, how, what measures and what to design for (Figures $3,4,5$ ).
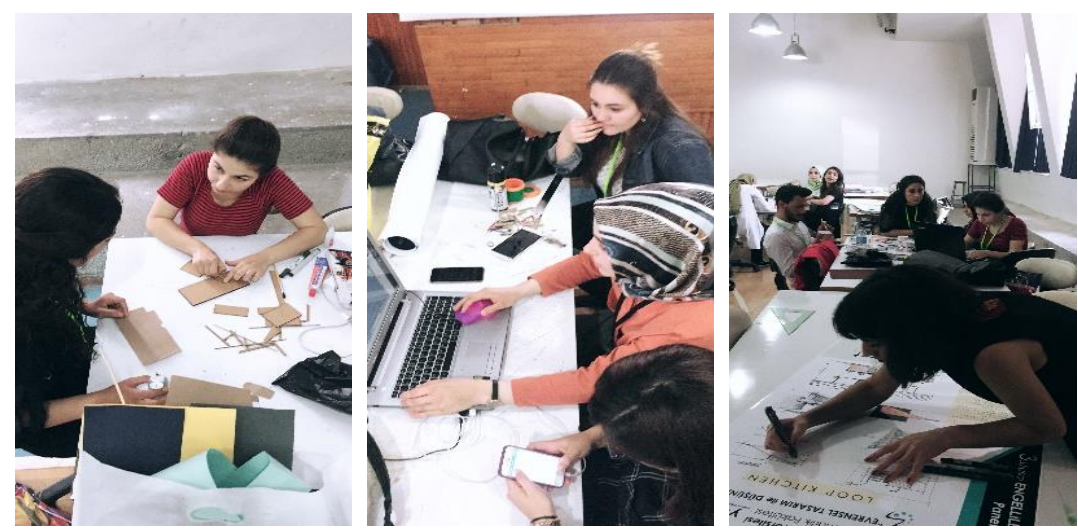

At the conclusion of the meeting; the space design group decided to design a universal kitchen for the orthopedically disabled individual who is a wheelchair user, the product design group decided to design an ergonomic and functional work table for the disabled individual with hand-arm deficiency, and the service
Figures 3, 4, 5. Group works carried out during the workshop 
design group decided to design an audio library for the sight disabled individual.

\section{FINDINGS}

The designs of spaces, products and services designed in accordance with universal design principles are given below at the end of the designing process, which run from 09.00 a.m. to 17.00 p.m. on the second day of the workshop.

\section{- "Loop Kitchen", designed with universal design principles in terms of space design}

The orthopedic disability prevents the body from performing its functions related to the movement. A space designed in this regard should enable the disabled individual to easily handle his own work. The students in the space design group of the workshop decided to design a universal kitchen after negotiations with students, disabled individuals and workshop directors. So as to find an answer to the question of how a universal kitchen should be; literature researches were made, existing samples were analysed, and new material samples and system details were searched.

The group participants completed their designs within the time given to them. To express the result products; technical details were given on the poster design (Figure 6), a model (Figure 7) was designed to facilitate the perception of the three-dimensional effect of the kitchen designed in the space, and a bookmarker (Picture 8) was designed to convey their own designs and give a social message to the other participant panelists and students at the workshop.

Figures 6, 7, 8. The poster, model and bookmarker designed by the space design group
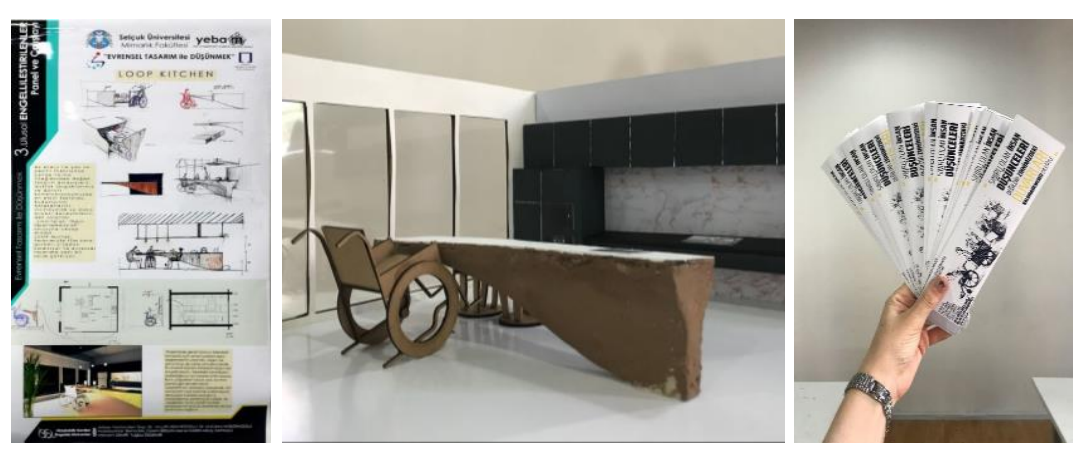

The kitchen design consists of a bench and an island module. The bottoms of all the cabinets in the bench module in front of the wall are left empty to a sufficient height at a level suitable for the knee distance on a sloping ground. This idea is an appropriate solution in terms of universal design principles. This allows the foot of the wheelchair to get down and more convenient access to the 
washbasins and drawers located on the module. Furthermore, the fact that the upper cabinets are designed with elevator system allows the cabinet shelves to be taken out and used. On the island module in the middle is the cooking section and the dining room. In this part which is designed aesthetically, attention has been paid to the under-bench spaces, allowing the disabled user to cook and serve without the need of another person. In addition, the cutoff boards mounted on the bench and the baskets mounted on the cabinet doors are also useful details.

\section{- "Zoom Table", designed with universal design principles in terms of product design}

With the product design group, it was decided to design a work and drawing table, which has many functions to meet the user needs at the same time, for the disabled individual with hand-arm deficiency who has undergraduate education in Interior Architecture. First of all, the body measurements of the disabled person were taken, compared with the standard measures, and then the first sketch was started to work in the direction of the individual's need.

During the time given to them, the group participants designed posters, models and a slogan. While there are technical and aesthetic information about the table they designed in the poster and also the suggestions of the materials to be used (Figure 9), a three-dimensional appearance of the table is seen on the model constructed as $1 / 5$ scale (Figure 10 ). It is meant to emphasize that everybody is likely to be disabled with a slogan saying "put your hand here and try taking off your jacket" with a white hand sign (Figure 11) written on a black background.
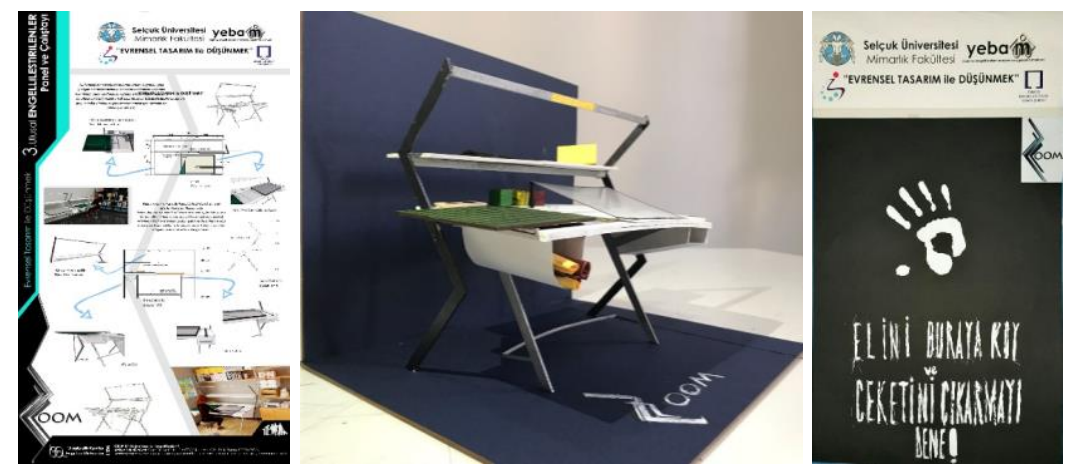

The first goal of this design, due to the discomfort in the left hand of the disabled person, is to reduce the power applied to the right hand of the individual. With this functional and operational details, the needs of the department where the users learn are also considered in this design and the user is allowed to make drawings and models. It is requested to meet all the needs of the

Figures 9, 10, 11. The poster, model and slogan designed by product design group 
user with the moving shelf system used on the table surface, linear lighting, illuminated glass surface, movable $t$ square, garbage cans on the sides of table and paper storage units.

\section{- "Modular Read-Listen City Element", designed with universal design principles in terms of service design}

The service design group decided to design modular read-listen city elements so that sight disabled individuals can socialize within the society and can easily carry out book-reading activities in the city centre. During the time given to them, the group participants designed a poster, a model and black glasses. The technical details of the service unit they designed on the poster were included (Figure 12). The three-dimensional appearance of the city element is seen on the model constructed as $1 / 20$ scale (Figure 13). With the black glasses they designed, other workshop participants were able to understand sight disabled individuals and put themselves in their place (Figure 14).

Figures 12, 13, 14. The poster, model and black glasses designed by the service design group
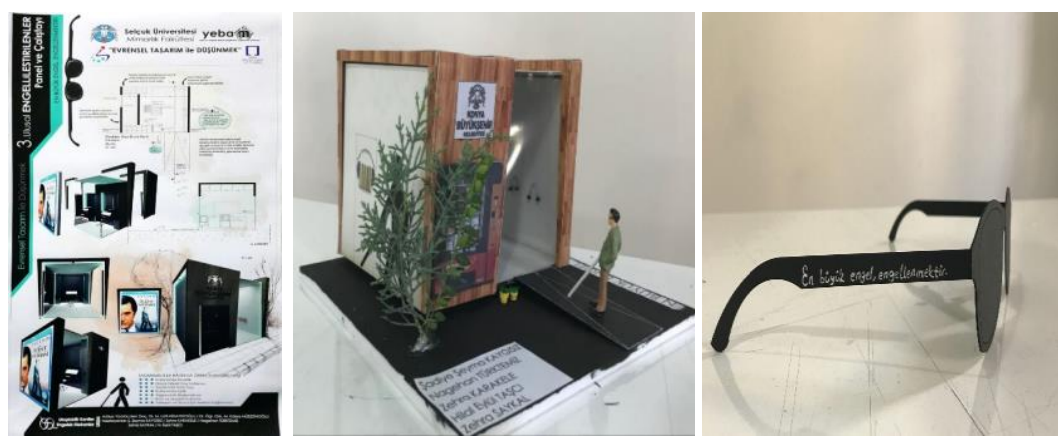

Designed for the sight disabled, the modular library is portable on suitable grounds and conditions and has easy-to-service details in the locality. Also considering wheelchair users, the bottom surfaces of the indoor fixtures are left empty and the entrance to the library is provided with a ramp. Access to the periodicals published with the Braille alphabet is provided in the modular library. With the internet service available in the library, appropriate environment conditions are provided for the individual to read daily newspapers, research, send and receive emails without needing anybody. In addition, they can also print a desired document as Braille Alphabet (relief).

\section{CONCLUSION}

When we look at the universal design approach covered in different design disciplines from a wider perspective, it is seen that the common point of all is the "user", and this design draws attention to the fact that the user exists at every stage of the approach. Although all the studies in the field of universal design until now seem to be a search for a solution to the problems of the 
disabled people at the first perception, they have a concept that goes beyond this intellectual basis, assess the size of the user at a wide range and seek solutions by approaching the usage problems with an integrative attitude.

Scissors, coffee pots and armrests for the left hander to use comfortably; sensor-fitted luminaires, doors, kitchen benches with empty bottoms and bathroom cabinets for the physically handicapped users; door handles opening in a single motion, without any additional or discretion, buses that incorporate wheelchair and baby car users without any additional or equipment; and smart cabinets designed for sight disabled individuals can be given as examples of spaces, products and services that are produced today with universal design conception. In order for these designs to reach the right circles, it is necessary to show empathy and recognize that each individual's needs may differ from one another.

Access of the universal design to the right place is only possible through education, and it is a holistic approach that includes designers, educators, employers and other segments of society. The designer has a different place here. By encouraging designers to recognize the power of designers to see or separate people as a factor in their design decisions and to encourage them to have a more critical view of how to make those decisions, universal design can be regarded as synonymous with good design. The way to do this is to develop the resources and curricula that provide universal design education and training for the designers of the future.

Universal design education should not only include students, but academics, instructors, graduate designers and design industry staff and be widely-esteemed. Human-oriented design education coincides with universal design. Presenting disabled individuals as a routine part of the society and ensuring the involvement of disabled people in social life depend also on the designs produced with universal design principles. The important thing is to ensure that this approach is used consciously.

\section{REFERENCES}

Akyol, E. (2009). Endüstriyel Tasarım Eğitiminde Evrensel Tasarım Algısı. Yüksek Lisans Tezi, Anadolu Ünversitesi, Fen Bilimleri Enstitüsü, Eskiş̧ehir.

Aytaç, S. (2005). İstihdam ve Koruma Alanı Yaratmak Üzere Özürlüler İçin Sosyal Yaşam. Sosyal Siyaset Konferansları, 49. Kitap, İstanbul. 
Beşer, E., Atasoylu, G., Akgör, Ş., Ergin, F., Çullu, E. (2006). Aydın İ Merkezinde Özürlülük Prevelansl, Etiyolojisi ve Sosyal Boyutu. TSK Koruyucu Hekimlik Bülteni 5(4); 267-275.

Birleşmiş Milletler Örgütü (2006). Engellilerin haklarına ilișkin sözleşme.http://www.un.org/disabilities/documents/nat 1/turkey.doc (Erişim tarihi:21.06.2018)

Bitner, M.J. (1990). Evaluating Service Encounters: The Effects of Physical Surroundings and Employee Responses. Journal of Marketing 54, (April), s. 69-82.

Boduroğlu, Ş. (2005). Konutlarda Evrensel Tasarım Kavramı ve Örnekler Üzerine Analizi. Mimar Sinan Güzel Sanatlar Üniversitesi, Fen Bilimleri Enstitüsü, İstanbul.

Değertekin, H.M. (2010). Engelliye Özel Değil Herkese Yönelik Tasarım: Herkes İçin Tasarım. 5nci Uluslararası Katılımlı Özürlüler Vakfı Kongre ve Sosyal Etkinlikleri 2010, Haliç Kongre Merkezi, 28-30 Mayıs, İstanbul.

Devlet İstatistik Enstitüsü (2004). Türkiye Özürlüler Araştırması 2002. Devlet İstatistik Enstitüsü Matbaası, Ankara.

Dostoğlu, N., Şahin, E., Taneli, Y. (2009). Dosya Tasarıma Kapsayıcı Yaklaşım:Herkes Íçin Tasarım. Mimarlık 347, MayısHaziran.

Evcil, A.N. (2014). Herkes İçin Tasarım. Boğaziçi Yayınları, İstanbul.

Goldsmith, S. (2000). Universal Design, A Manual of Practical Guidance for Architects. Woburn: Reed Educational and Professional Publishing.

Hanson, J. (2004). The Inclusive City: Delivering A More Accessible Urban Environment Through Inclusive Design. International Construction Conference Responding to Change, 7-8 September 2004.

Hazer, 0. (2005). Evde Kullanılan Araç-Gereç ve Ekipmanlar: Özürlüler İçin Ergonomik Bir Yaklaşım. Hacettepe Üniversitesi, İktisadi ve İdari Bilimler Fakültesi Aile ve Tüketici Bilimleri Bölümü, Ankara.

International Labor Organisation (2008). ILO Disability Programme.http://www.ilo.org/public/english/employ ment/skills/disability/iloprog.htm(Erişimtarihi:15.05.20 18)

Jacobs, J. (1961). The Death and Life of Great American Cities: The Failure of Town Planning. New York: Random House Inc.

Kavak, M. (2010). Evrensel Tasarım Yaklaşımı Bağlamında Kamusal Mekanlar:Harbiye Kongre Vadisi Örneği. Yüksek Lisans Tezi, Bahçeşehir Üniversitesi, İstanbul.

Manley, S. (2000). Creating An Accesible Public Realm. (Chapter 58). (Ed: Preiser, W.F.E. and Ostroff , E.) Universal Design Handbook, McGraw Hill, New York,USA.

Olguntürk, N. (2007). Evrensel Tasarım:Tüm Yaşlılar, Farklı Yetenekler ve Çeşitli İnsanlık Durumları için Tasarım. Bilkent Üniversitesi, TMMOB Mimarlar Odası Ankara Şubesi, Bülten 4. s.6-9.

Oliver, R.L. (1997). Satisfaction: a Behavioral Perspective on the Consumer. MA: Irwin, Boston: Mc Graw Hill. 
User-Involved Universal Design Experience in The Space,

Product and Service Development Process

Ostroff, E. (2001). Universal Design: the New Paradigm. Universal Design HandBook, (Ed: W. Preiser and E. Ostroff), Newyork: McGraw-Hill, ss. 1.3-1.12.

Preiser, W.F.E. (2008). Universal Design: From Policy to Assessment Research and Practice. International Journal of Architectural Research, Vol:2, Issue: 2, Page:78-93.

Steinfeld E. and Maisel J.L. (2012). Universal Design Creating Inclusive Environment. (Ed: John Wiley \& Sons), Inc.. Hoboken, New Jersey.

Story, M.F. (2001). Principles of Universal Design. Universal Design HandBook (Ed: W. Preiser, E. Ostroff), Newyork: McGrawHill, ss. 10.3-10.19.

Tutal, O. (2013). Hala Tercihli Bir Yaklaşım: Herkes İçin Tasarım. Herkes İçin Tasarım Müfredatı Geliştirme Çalıştayı, s. 108.

United Nations (1975). Declearation on the Rights of Disabled Persons. http://www.unhchr.ch/html/menu3/b/72.htm (Erişim tarihi:15.06.2018)

URL1http://www.who.int/ (Erişim tarihi: 08.07.2018)

URL2http://www.tuik.gov.tr/PreTablo.do?alt_id=1017 (Erişim tarihi: 12.06.2018)

URL3https://tr.pinterest.com/pin/495396027752172898/?lp=t rue (Erişim tarihi:08.07.2018)

URL4http://www.hafeleevim.com/urun-gruplari/mutfakdonanimlari/asansor-sistemi/(Erişim tarihi:08.07.2018)

URL5http://www.core77designawards.com/2011/recipients/k orea-smart-card-open-gatesystem/( Erişim tarihi:02.07.2018)

URL6https://id.metu.edu.tr/tr/2017/11/15/ataman-ozdemirengelsiz-erisim-sistemleri-ile-good-design-japan-2017ve-design-turkey-2017-odullerininsahibi/ (Erişim tarihi:02.07.2018)

URL7https://www.enteresan.com/evrensel-tuvalet-prototipi (Erişim tarihi:02.07.2018)

URL8https://naturalearning.org/nli-projects/kids-togetherplayground-post-occupancy-evaluation/ (Erişim tarihi:02.07.2018)

URL9 https://get.wewalk.io/(Erişim tarihi:02.07.2018)

URL10https://economictimes.indiatimes.com/slideshows/techlife/simple-and-compact-multi-function devices/panasonics-cordless-steam iron/slideshow/28656641.cms (Erişim tarihi:02.07.2018)

URL11http://www.gyenno.com/spoon-en.html (Erişim tarihi:02.07.2018)

URL12https://tr.fiskars.com/urunler/makaslar (Erişim tarihi:02.07.2018)

URL13https://tagpblog.wordpress.com/2015/09/16/alzheimer -hastalari-icin-tasarlanmis-renkli-eglenceli-yemektakimlari/(Erişim tarihi:02.07.2018)

URL14https://tr.pinterest.com/pin/331014641332712637/ (Erişim tarihi:02.07.2018)

URL15https://www.apple.com/tr/accessibility/watch/vision/ (Erişim tarihi:02.07.2018)

URL16http://news.mit.edu/2015/finger-mounted-readingdevice-blind-0310 (Erişim tarihi:02.07.2018) 
URL17https://itunes.apple.com/us/app/seeingai/id999062298 ? $\mathrm{mt}=8$ (Erişim tarihi:02.07.2018)

Uskun, E., Öztürk, M., Kişioğlu, A.N. (2005). Isparta İlinde Özürlülük, Sakatlık ve Engellilik Epidemiyolojisi. Sağlık ve Toplum Dergisi 1; 1-15.

Vezzoli, C., Kohtala, C. and Srinivasan, A. (2014). Product- Service System Design for Sustainability. sy. 35-37.

Zec, P. (2009). Universal Design Best Practice. Red Dot Edition, Essen, Germany.

Zimmermann, R. (2006). Building Operating Management. 53, 11, Career and Technical Education.

\section{Resume}

Mehmet Lutfi Hidayetoglu is Associate Professor of Industrial Design at Selcuk University in Turkey. He was assigned to Interior Architecture and Environmental Design Department, Faculty of Arts in Selcuk University as a Research Associate in 2005. He participated in many exhibitions with his designs and published numerous academic papers about interior architecture, sustainability, smart environment, spatial perception, environmental psychology, colour, light, traditional civil architecture and furniture designs.

Mensure Kubra Muezzinoglu is an interior architecture and environmental designer and works at as a Dr. Inst. in Selcuk University faculty of Fine Arts. She got her B.Sc in 2007 in Selcuk University on interior architecture and enviromental design, Msc in 2010 in Selcuk University and PhD in 2018 in Selcuk University on architecture. Her main research topic has been the analysis of interior space and user satisfaction in connection with the visual perception of space. 